\title{
PENGEMBANGAN METODE GC-MS UNTUK PENETAPAN KADAR ACETAMINOPHEN PADA SPESIMEN RAMBUT MANUSIA
}

\author{
Komang Ari Gunapria Darmapatni*, Achmad Basori dan Ni Made Suaniti \\ Program Studi Magister Ilmu Forensik, Sekolah Pascasarjana, UNAIR, Surabaya \\ Email : argun4sma@yahoo.com
}

\begin{abstract}
ABSTRAK
Rambut dapat digunakan sebagai pilihan dalam melakukan analisis senyawa obat di dalam tubuh khususnya pada kasus-kasus penyalahgunaan obat atau keracunan yang bersifat kronik. Telah dilakukan penelitian yang bertujuan untuk mengembangan metode untuk penetapan kadar acetaminophen pada spesimen rambut manusia menggunakan instrumen GC-MS. Sampel rambut diambil pada panjang 0-3 cm, 0-6 $\mathrm{cm}$ dan $0-10 \mathrm{~cm}$ pada 10 orang pasien yang mendapatkan terapi parasetamol. Preparasi sampel terdiri dari tahap dekontaminasi, destruksi, ekstraksi dan derivatisasi pada masing-masing spesimen rambut. Kemudian ekstrak diinjeksikan pada sistem GC-MS. Hasil penelitian menunjukkan bahwa acetaminophen dapat terdeteksi pada spesimen rambut dalam bentuk acetaminophen-TMS akibat adanya perlakuan derivatisasi menggunakan BSTFA yang mengandung TMCS $1 \%$. Pada panjang spesimen rambut $0-3 \mathrm{~cm}$ diperoleh konsentrasi $0,1761-0,3392 \mathrm{ng} / \mathrm{mg}$ spesimen rambut, pada panjang spesimen rambut 0-6 $\mathrm{cm}$ diperoleh hasil 0,2081-0.4845 ng/mg spesimen rambut dan pada panjang spesimen rambut 0 $10 \mathrm{~cm}$ konsentrasi acetaminophen-TMS dalam sampel adalah 0,2473-0,5782 ng/mg spesimen rambut.
\end{abstract}

Kata kunci : acetaminophen, rambut, Gas Chromatography - Mass Spectrometry

\begin{abstract}
Hair can be used as an option in the analysis of drug compounds in the body, especially in cases of drug abuse or poisoning that is chronic. There are previous researches that have aimed to develop the method for the determination of acetaminophen levels in specimens of human hair using GC-MS. The data was taken from the hair samples that are 0-3 cm long, 0-6 cm long and 0$10 \mathrm{~cm}$ in 10 patients treated with paracetamol. Sample preparation consists of decontamination, destruction, extraction and derivatization processes on each hair specimen. Then the extract was injected into the GC-MS system. The results showed that acetaminophen can be detected in hair specimens in the form of acetaminophen-TMS as a result of the derivatization treatment using BSTFA containing $1 \%$ of TMCs. At the $0-3 \mathrm{~cm}$ long hair specimens, it was obtained the concentration of 0.1761 to $0.3392 \mathrm{ng} / \mathrm{mg}$ of hair specimens; at the $0-6 \mathrm{~cm}$ long hair specimens, it was obtained the concentration of 0.2081 to $0.4845 \mathrm{ng} / \mathrm{mg}$ of hair specimens; and at the $0-10 \mathrm{~cm}$ long hair specimens, acetaminophen-TMS concentration in the sample was 0.2473 to 0.5782 $\mathrm{ng} / \mathrm{mg}$ of hair specimens.
\end{abstract}


Jurnal Biosains Pascasarjana Vol. 18 (2016) pp (C) (2016) Sekolah Pascasarjana Universitas Airlangga, Indonesia

Keyword : acetaminophen, human hair, Gas Chromatography - Mass Spectrometry 


\section{PENDAHULUAN}

Pada tahun 2014 telah terjadi berbagai macam kasus keracunan dan penyalahgunaan obat-obatan. Berdasarkan data yang dikutip dari website Badan Pengawas Obat dan Makanan, pada tahun 2014 mengenai kasus keracunan diperoleh hasil bahwa keracunan disebabkan oleh beberapa salah satunya adalah penyalahgunaan obat-obatan selain NAPZA.

Monitoring senyawa obat dalam tubuh dapat dilakukan melalui cairan tubuh seperti urin, keringat, saliva dan darah. Rambut dalam berbagai kasus kriminal digunakan untuk mengetahui kecocokan deoxyribonucleic acid (DNA) namun rambut juga dapat digunakan sebagai pilihan dalam melakukan analisis senyawa obat didalam tubuh. Kelebihan penggunaan spesimen rambut dibandingkan urin dan darah untuk menganalisis obat adalah rambut memiliki informasi keberadaan obat yang lebih lama dengan rentang waktu minggu hingga bulan dibandingkan pada urin atau darah yang hanya mendeteksi dengan kisaran waktu beberapa jam hingga beberapa hari (Kintz, 2000). Han et al. (2012) menggunakan spesimen rambut dengan panjang rambut yang berbeda yakni 0-3 $\mathrm{cm}, 3-6 \mathrm{~cm}, 6-9 \mathrm{~cm}, 9-12 \mathrm{~cm}$ untuk menganalisis Tetrahydrocanabinol (THC). Berdasarkan penelitian ini diketahui bahwa konsentrasi rata-rata THC pada panjang 0-3 $\mathrm{cm}$ lebih besar dibandingkan $9-12 \mathrm{~cm}$.

Di Inggris pada tahun 2000 hingga 2008 sebesar 90 hingga 155 orang meninggal akibat keracunan acetaminophen tiap tahunnya (Hawton et al., 2011). Acetaminophen merupakan analgesik-antipiretik non opioid dan anti-inflamasi non-steroid (AINS). Acetaminophen dan metabolitnya memiliki sifat yang cenderung polar (Hansen et al., 2012). Acetaminophen meniru cara keja dari heroin (Aronson, 2014) sehingga sering digunakan secara bersama-sama dengan analgesik opioid untuk meningkatkan efektivitas analgesik dan menurunkan kebutuhan akan analgesik opioid tersebut (Curatolo and Sveticic, 2002). Selain itu penggunaan acetaminophen dengan alkohol juga meningkatkan risiko nekrosis hati pada penggunanya (Mozayani dan Raymond, 2002).

Konsentrasi obat dalam spesimen rambut relatif rendah sehingga diperlukan teknik ekstraksi yang tepat serta instrumen yang mendukung untuk menganalisis suatu senyawa dalam konsentrasi yang kecil salah satu instrument yang dapat mendeteksi suatu senyawa hingga $<1 \mathrm{ng} / \mathrm{g}$ adalah Gas Chromatography-Mass Spectrometry (GC-MS). Selain instrumen yang tepat dibutuhkan juga teknik khusus sebelum sampel diinjeksikan ke dalam sistem GC-MS, salah satunya adalah teknik derivatisasi. Teknik ini digunakan apabila senyawa yang ingin diketahui keberadaannya cenderung sulit menguap dan tidak stabil pada suhu tinggi.

Penelitian ini bertujuan untuk mengetahui apakah senyawa acetaminophen dapat terdeteksi pada spesimen rambut pasien yang mendapatkan terapi parasetamol serta mengetahui pengaruh panjang spesimen rambut terhadap konsentrasi acetaminophen pada spesimen rambut manusia. Analisis dilakukan dengan menggunakan GC-MS dengan tambahan perlakuan derivatisasi menggunakan N,O-bis (trimetilsilil) trifluoroasetamida (BSTFA) yang mengandung trimetilklorosilan (TMCS) $1 \%$.

Upaya untuk menjamin bahwa prosedur analisis yang dipilih akan memberikan hasil yang valid dan dapat dipercaya maka harus dilakukan validasi metode. Adapun uji yang dilakukan dalam validasi metode antara lain : linieritas, batas deteksi/LoD (Limit of Detection), batas kuantitasi/LoQ (Limit of Quantitation), accuracy dan precision. Selain uji validasi dilakukan juga uji statistik untuk memastikan hasil yang diperoleh memiliki makna berdasarkan statistik. 


\section{TINJAUAN PUSTAKA}

\subsection{Rambut}

Rambut merupakan salah satu bagian tubuh yang memiliki bentuk seperti benang yang tumbuh dari akar rambut yang ada dalam lapisan dermis dan melalui saluran folikel rambut ke luar dari kulit. Komponen kimia rambut terdiri atas 0.1-5 pigmen (melanin), 19\% lemak, dan $65-95 \%$ protein serta komponen-komponen lainnya seperti polisakarida dan air (Kintz, 2007). Clay et al., (1940) menemukan bahwa dalam rambut yang berwarna hitam mengandung lebih banyak kandungan protein sistein (Asquith, 1977)

Rambut kepala dihasilkan selama periode waktu 4-8 tahun sedangkan non rambut kepala dihasilkan selama periode kurang dari 12 bulan dengan pertumbuhan rata-rata $0,6-1,42$ $\mathrm{cm}$ per bulan hal ini tergantung pada tipe rambut dan lokasi tumbuhnya (Saitoh, 1969). Tingkat pertumbuhan rambut kulit kepala manusia adalah sekitar $0,35 \mathrm{~mm}$ per hari pada pria dan wanita, namun hal ini sangat bervariasi (Kintz, 2007).

Berdasarkan penelitian Pötsch (1996) ditemukan beberapa variasi pertumbuhan rambut yakni 0,07 dan $0,78 \mathrm{~mm}$ per hari sedangkan $82 \%$ dari populasi penelitian mempunyai variasi antara 0,32 dan $0,46 \mathrm{~mm}$ per hari. Siklus pertumbuhan rambut manusia dimulai dengan fase anagen atau fase pertumbuhan, yaitu folikel berkembang dan rambut diproduksi. Durasi fase anagen sangat bervariasi dan biasanya berlanjut antara 7-94 minggu, namun dapat berlangsung selama beberapa tahun, tergantung pada daerah anatominya (Castanet and Ortonne,1997). Catagen adalah fase regresi, yaitu ketika aktivitas bola folikel berhenti dan dermal papila mengkerut ketika folikel mendekati fase istirahat, telogen, kemudian setelah fase telogen, siklus pertumbuhan lain dimulai (Kintz, 2007). Gambar 2.1 Struktur folikel rambut (Kintz, 2007) sedangkan Gambar 2.2 Fase pertumbuhan rambut (Kintz, 2007)

Baugartner (1979) melakukan penelitian keberadaan metabolit morfin pada sampel rambut yang berasal dari seorang pengguna heroin dengan metode radioimmunoassay (RIA), diperoleh hasil bahwa perbedaan konsentrasi morfin dalam sepanjang helai rambut tersebut berhubungan dengan waktu pemakaian. Terdapat tiga model penyatuan obat yang telah diteliti antara lain : obat bisa masuk ke dalam rambut melalui (1) difusi aktif atau pasif dari aliran darah yang memenuhi papila dermal, (2) difusi dari keringat dan sekresi lainnya membasahi serat rambut yang tumbuh atau yang sudah dewasa, atau (3) obat eksternal dari uap atau serbuk yang berdifusi ke dalam serat rambut dewasa (Kintz, 2007).. Gambar 2.3 menunjukkan mekanisme distribusi obat ke dalam rambut.

\subsection{Parasetamol}

Parasetamol mempunyai rumus molekul $\mathrm{C}_{8} \mathrm{H}_{9} \mathrm{NO}_{2}$ dengan berat molekul 151,16 g/mol. Nama lain dari parasetamol adalah acetaminophen atau 4-hidroksi asetalinida. Parasetamol memiliki kelarutan sangat rendah bila dilarutkan dalam pelarut nonpolar seperti toluena. Pada alkohol kelarutan parasetamol akan menurun dengan peningkatan panjang rantai karbon sedangkan dalam air kelarutan parasetamol jauh lebih rendah daripada di pelarut polar lainnya seperti alkohol (Granberg and Rasmuson, 1999). Acetaminophen dapat membentuk ikatan dengan gugus thiol pada sistein (Lemke et al. 2007).

Penelitian Saito (2008) telah berhasil melakukan analisis acetaminophen menggunakan spesimen rambut pada kasus keracunan dalam kondisi overdose (OD). Dari penelitian ini diketahui pula bahwa limit deteksi GC-MS adalah $0,1 \quad \mathrm{ng} / \mathrm{mg}$ dengan 
jumlah spesimen rambut yang digunakan sebanyak $20 \mathrm{mg}$.

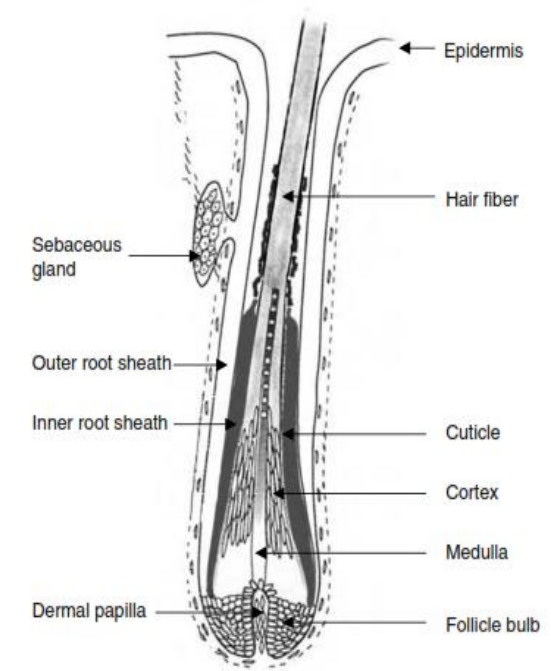

Gambar 2.1 Struktur folikel rambut (Kintz, 2007)

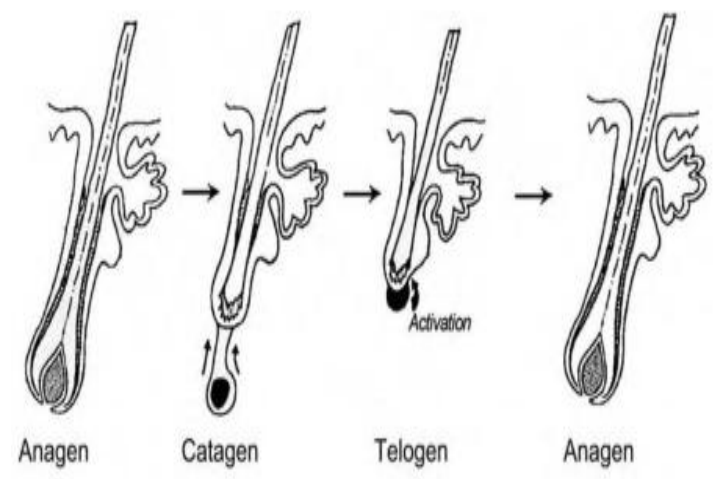

Gambar 2.2 Fase pertumbuhan rambut (Kintz, 2007)

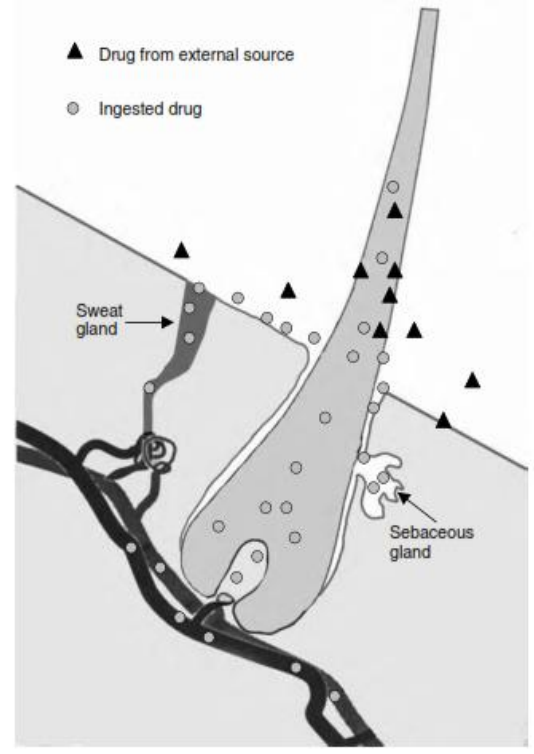

Gambar 2.3 Mekanisme distribusi obat ke dalam rambut (Kintz, 2007)

\subsection{GC-MS}

Teknik GC pertama kali diperkenalkan oleh James dan Martin pada tahun 1952 (Sparkman et al., 2011). GC merupakan salah satu teknik kromatografi yang hanya dapat digunakan untuk mendeteksi senyawasenyawa yang mudah menguap. Kriteria menguap adalah dapat menguap pada kondisi vakum tinggi dan tekanan rendah serta dapat dipanaskan (Drozd, 1985).

Dasar pemisahan menggunakan kromatografi gas adalah penyebaran cuplikan pada fase diam sedangkan gas sebagai fase gerak mengelusi fase diam. Cara kerja dari GC adalah suatu fase gerak yang berbentuk gas mengalir di bawah tekanan melewati pipa yang dipanaskan dan disalut dengan fase diam cair atau dikemas dengan fase diam cair yang disalut pada suatu penyangga padat. Analit tersebut dimuatkan ke bagian atas kolom melalui suatu portal injeksi yang dipanaskan. Suhu oven dijaga atau diprogram agar meningkat secara bertahap. Ketika sudah berada dalam kolom, terjadi proses pemisahan antar komponen. Pemisahan ini akan bergantung pada lamanya waktu relatif yang dibutuhkan oleh komponen- 
komponen tersebut di fase diam (Sparkman et al., 2011).

Seiring dengan perkembangan teknologi maka instrument GC digunakan secara bersama-sama dengan instrumen lain seperti Mass-Spectrometer (MS).

Spektrometer massa diperlukan untuk identifikasi senyawa sebagai penentu bobot molekul dan penentuan rumus molekul. Prinsip dari MS adalah pengionan senyawa-senyawa kimia untuk menghasilkan molekul bermuatan atau fragmen molekul dan mengukur rasio massa/muatan. Molekul yang telah terionisasi akibat penembakan elektron berenergi tinggi tersebut akan menghasilkan ion dengan muatan positif, kemudian ion tersebut diarahkan menuju medan magnet dengan kecepatan tinggi. Medan magnet atau medan listrik akan membelokkan ion tersebut agar dapat menentukan bobot molekulnya dan bobot molekul semua fragmen yang dihasilkan (David, 2005). Kemudian detektor akan menghitung muatan yang terinduksi atau arus yang dihasilkan ketika ion dilewatkan atau mengenai permukaan, scanning massa dan menghitung ion sebagai mass to charge ratio $(\mathrm{m} / \mathrm{z})$. Terdapat 4 (empat) proses dalam spektrometri massa yakni ionisasi, percepatan, pembelokkan dan pendeteksian.

Derivatisasi merupakan proses kimiawi untuk mengubah suatu senyawa menjadi senyawa lain yang mempunyai sifat-sifat yang sesuai untuk dilakukan analisis menggunakan kromatografi gas atau menjadi lebih mudah menguap. Hal ini dilakukan jika suatu senyawa diketahu sulit menguap maka dilakukan derivatisasi terlebih dahulu sebelum dianalisis menggunakan GC. (Drozd, 1985).

Derivatisasi dilakukan karena terdapat senyawa-senyawa dengan berat molekul besar yang biasanya tidak mudah menguap karena adanya gaya tarik-menarik inter molekuler antara gugus-gugus polar atau yang mengadung hidrogen aktif seperti SH, $\mathrm{OH}$, -NH dan - $\mathrm{COOH}$ maka jika gugus- gugus polar ini ditutup dengan cara derivatisasi akan mampu meningkatkan volatilitas senyawa. Selain itu beberapa senyawa volatil mengalami dekomposisi parsial karena panas sehingga diperlukan derivatisasi untuk meningkatkan stabilitasnya (Drozd, 1985).

Sililasi merupakan salah satu proses derivatitasi dengan menghasilkan produk berupa derivatif silil yang sangat volatil, dan lebih stabil pada suhu yang tinggi. Cara kerja dari penderivat tipe silil ini adalah dengan mengganti gugus hidrogen $(\mathrm{H})$ dengan trimetilsilil atau TMS (Regis, 1998).

\section{METODE PENELITIAN}

3.1 Bahan penelitian Spesimen yang digunakan dalam penelitian ini adalah rambut. Bahan kimia yang digunakan dalam penelitian ini adalah bahan kimia dalam derajat pro analisis (p.a) yang terdiri dari diklorometana $\left(\mathrm{CH}_{2} \mathrm{Cl}_{2}\right)$, metanol $\left(\mathrm{CH}_{3} \mathrm{OH}\right)$, standar pembanding acetaminophen dan N,O-bis (trimetilsilil) trifluoroasetamida (BSTFA) yang mengandung trimetilklorosilan (TMCS) 1\% yang diperoleh dari Sigma Aldrich Chemical Singapore.

\subsection{Instrumen penelitian}

Alat yang digunakan meliputi alat-alat gelas yang umum digunakan dalam laboratorium analisis, box es, pipet mikro dengan ukuran $1000 \mu \mathrm{L}$ (200-1000 $\mu \mathrm{L})$ dan $20 \mu \mathrm{L}(2-20 \mu \mathrm{L})$, neraca analitik, gunting stainless steel, wadah plastik bertutup, Gas Chromatography (GC) tipe Agilent $6890 \mathrm{~N}$ dengan kolom kapiler HP-5ms $(30 \mathrm{~m} \times 0,25 \mathrm{~mm} \times 0,25 \mu \mathrm{m})$ dan detektor Mass Spectrometry (MS) tipe Agilent 5973.

3.3 Pengumpulan data

$$
\begin{aligned}
& \text { 3.3.1Preparasi Larutan Standar } \\
& \text { Parasetamol } \\
& \text { Sebanyak } 1 \mathrm{mg} \text { standar } \\
& \text { parasetamol ditimbang, kemudian }
\end{aligned}
$$


dilarutkan dengan metanol (98\%) dalam labu ukur $10 \mathrm{~mL}$ hingga tanda batas sehingga diperoleh larutan standar parasetamol dengan konsentrasi 100 ppm. Kemudian larutan standar parasetamol $100 \mathrm{ppm}$ dipipet berturutturut $0,3 \mathrm{~mL} ; 0,7 \mathrm{~mL} ; 1 \mathrm{~mL} ; 1,5 \mathrm{~mL}$ dan $2 \mathrm{~mL}$, dimasukkan masing-masing dalam labu $10 \mathrm{~mL}$ dan ditambahkan metanol 98\% hingga tanda batas sehingga diperoleh konsentrasi larutan standar yakni 3 ppm, 7 ppm, 10 ppm, 15 ppm dan $20 \mathrm{ppm}$. Seluruh larutan standar diderivatisasi sebelum diinjeksikan ke sistem GC-MS.

\subsubsection{Ekstraksi spesimen rambut simulasi \\ Spesimen rambut yang} diperoleh dari orang sehat, $100 \mathrm{mg}$ spesimen rambut didekontaminasi terlebih dahulu, dihomogenasi, dan diekstraksi dengan $1 \mathrm{~mL}$ larutan acetaminophen $10 \mathrm{ppm}$ pada suhu $45^{\circ} \mathrm{C}$ selama 2 jam. Ekstrak cairnya di sentrifugasi dengan kecepatan 5000 rpm selama 5 menit. Ekstrak diuapkan hingga $990 \mu \mathrm{L}$. Kemudian sebanyak 10 $\mu \mathrm{L}$ BSTFA yang sudah mengandung TMCS $1 \%$ ditambahkan ke dalam ekstrak. Tabung disegel dan dipanaskan pada $60^{\circ} \mathrm{C}$ selama 20 menit. Setelah derivatisasi, spesimen didinginkan sampai suhu kamar. Sebanyak $1 \mu \mathrm{L}$ spesimen hasil derivatisasi disuntikkan ke dalam kondisi GC-MS terpilih.

\subsubsection{Preparasi dan analisis spesimen rambut}

Analisis pada rambut dilakukan pada 10 orang pasien (sukarelawan) yang mendapatkan terapi tablet parasetamol yang sama pada dosis terapi. Masing-masing spesimen rambut dipotong dengan panjang $0-3 \mathrm{~cm}, 0-6$ $\mathrm{cm}$ dan 0-10 $\mathrm{cm}$.

Setiap helai rambut diperoleh
dengan cara rambut digunting
menggunakan gunting stainless steel.
Rambut diambil pada bagian depan,
atas, samping kanan, samping kiri, dan

bagian belakang. Kemudian dimasukkan ke dalam wadah plastik dan disimpan pada suhu ruang (Wijayaputra, 2011).

Sebanyak $200 \mathrm{mg}$ spesimen rambut ditimbang. Kemudian didekontaminasi dengan $5 \mathrm{~mL}$ diklorometana selama 2 menit pada suhu ruang, $5 \mathrm{~mL}$ air hangat selama 2 menit dan $5 \mathrm{~mL}$ diklorometana selama 2 menit (Saito, 2008). Setelah didekontaminasi, spesimen rambut digunting menjadi kecil dan diinkubasi pada $45^{\circ} \mathrm{C}$ selama 2 jam dalam $1 \mathrm{~mL}$ metanol. Kemudian lapisan air ditampung dan disentrifugasi dengan kecepatan $5000 \mathrm{rpm}$ selama 5 menit (Wijayaputra, 2011). Supernatan yang diperoleh diambil dan diuapkan menggunakan nitrogen. Residu yang diperoleh kemudian diderivatisasi. Sebanyak $10 \mu \mathrm{L}$ BSTFA dengan TMCS $1 \%$ ditambahkan ke residu. Tabung disegel dan dipanaskan pada $60^{\circ} \mathrm{C}$ selama 20 menit. Setelah derivatisasi, spesimen didinginkan sampai suhu kamar. Sebanyak $1 \mu \mathrm{L}$ spesimen hasil derivatisasi disuntikkan ke dalam sistem GC-MS.

\subsubsection{Cara Pengolahan dan Analisis Data \\ Data yang diperoleh dari} penelitian ini akan berupa kromatogram dengan puncak (peak), waktu retensi (tR) dan luas puncak yang kemudian dilakukan perhitungan untuk validasi metode dan konsentrasi senyawa parasetamol. Konsentrasi senyawa acetaminophen dalam spesimen rambut diperoleh dengan cara luas puncak spesimen diplotkan dalam persamaan regresi linier standar sehingga diperoleh konsentrasi acetaminophen dalam spesimen rambut pasien. Kemudian dilakukan uji statistic regresi linier sederhana menggunakan software IBM SPSS Statistics 24.

4.4 Validasi metode

4.4.2 Linieritas

Uji linieritas dilakukan dengan cara membuat persamaan regresi linier 
berdasarkan konsentrasi dan area, dengan rumus :

dengan,

$$
y=b x+a
$$

$$
\begin{aligned}
& \mathrm{y}=\text { luas puncak (peak area) } \\
& \mathrm{x}=\text { konsentrasi zat }
\end{aligned}
$$

kemudian dihitung harga koefisien korelasi.

4.4.3 Penentuan batas deteksi (LoD) dan batas kuantitasi (LoQ)

Untuk menentukan LoD dan

LoQ dapat digunakan rumus :

$$
\begin{aligned}
& \mathrm{LOD}=\frac{3 x s\left(\frac{y}{x}\right)}{\text { slope }} \quad \mathrm{S}(\mathrm{y} / \mathrm{x})=\sqrt{\frac{(Y-Y i)}{n-2}} \\
& \mathrm{LOQ}=\frac{10 x s\left(\frac{y}{x}\right)}{\text { slope }}
\end{aligned}
$$

\subsubsection{Akurasi (persen recovery)}

Untuk menentukan akurasi maka dilakukan perhitungan persen recovery atau perolehan kembali menggunakan ekstrak cair spesimen rambut simulasi. Digunakan rumus nilai recovery:

$$
\text { Recovery }=\frac{M 2}{M 1} \times 100 \%
$$

\subsubsection{Presisi}

Presisi diperoleh dengan menginjeksikan masing-masing standar acetaminophen sebanyak 3 (tiga) kali, kemudian dihitung nilai presisi berdasarkan harga koefisien variasi, dengan rumus :

$$
\mathrm{CV}=\frac{s b}{\bar{X}}
$$

dengan,

$S_{\mathrm{b}}:$ simpangan baku relatif

$\bar{X}$ : harga rata-rata dari banyaknya pengukuran

\section{HASIL DAN PEMBAHASAN}

\subsection{Validasi Metode Penelitian}

Berdasarkan hasil analisis terlihat bahwa pada blanko tidak ditemukan puncak yang merupakan senyawa acetaminophen, sedangkan pada larutan standar terkonsenrasi menunjukkan puncak senyawa acetaminophen dalam bentuk derivatnya yakni acetaminophen-TMS pada waktu retensi 18.10 pada mode Full Scan dan 18.09 pada mode SIM (Selected Ion Monitoring).

Mode Full Scan merupakan mode untuk menganalisis keseluruhan senyawa dalam sampel, sedangkan mode SIM merupakan mode operasi tanpa merekam keseluruhan spektra, namun hanya ion-ion tertentu (Moffat, et al., 2004). Mode Full Scan dilakukan terlebih dahulu guna memastikan senyawa apa yang terdapat dalam sampel tersebut, kemudian jika senyawa yang dicari telah ditemukan maka dilakukan analisis dengan mode SIM, mode SIM relatif lebih peka dikarenakan dengan mode SIM senyawa-senyawa dengan ion-ion fragmentasi yang diinginkan atau dengan kelimpahan yang tinggi saja yang akan dideteksi walaupun konsentrasinya relatif rendah.

Pada penelitian ini digunakan ion fragmentasi 166, 181, dan 223 karena memiliki kelimpahan relative lebih tinggi dan spesifik. Hal ini terbukti bila ditinjau dan membandingkan hasil analisis full scan dan SIM. Pada mode full scan semua senyawa yang ada pada ekstrak terdeteksi oleh instrumen, namun pada mode SIM hanya terlihat 1 puncak yang merupakan acetaminophen-TMS.

\subsubsection{Linieritas}

Linieritas berfungsi untuk membuktikan hubungan linier antara konsentrasi dan peak area. Berdasarkan perhitungan diketahui bahwa nilai koefisien korelasi $(r)=0,9950$. Nilai koefisien korelasi yang mendekati +1 menunjukkan adanya korelasi positif yang kuat antar variabel sedangkan berdasarkan nilai koefisien determinasi $\left(\mathrm{R}^{2}\right)$ sebesar 0.9901 yang menunjukkan bahwa variabel $\mathrm{X}$ (konsentrasi larutan standar) mempengaruhi variabel $\mathrm{Y}$ (luas area) sebesar 99,01\%. 


\subsubsection{Presisi}

Nilai presisi dihitung berdasarkan harga koefisien variasi. Tabel 4.1 menunjukkan harga koefisien variasi masing-masing larutan standar acetaminophen. Nilai presisi dihitung berdasarkan harga koefisien variasi. Nilai \% RSD menyatakan tingkat ketelitian analisis, semakin kecil nilai \% RSD maka makin teliti tingkat ketelitiannya, namun hal ini disesuaikan dengan konsentrasi komponen terukur dalam sampel. Semakin kecil konsentrasi komponen maka semakin besar nilai \% RSD yang dihasilkan.

Tabel 4.2 menunjukkan tingkat presisi berdasarkan konsentrasi analit yang dianalisis yang dikutip dari American pre-Veterinary Medical Assosiation (2004) sedangkan berdasarkan Association of Analytical Communities (AOAC) tingkat presisi disesuaikan juga dengan konsentrasi komponen dalam sampel. Tabel 4.3 menunjukkan tingkat presisi disesuaikan juga dengan konsentrasi komponen dalam sampel berdasarkan AOAC.

Tabel 4.1 Harga koefisien variasi masing-masing larutan standar acetaminophen

\begin{tabular}{lcc}
\hline No & $\begin{array}{c}\text { Konsentrasi } \\
\text { (ppm) }\end{array}$ & \% RSD \\
\hline 1. & 3 & $17.5 \%$ \\
2. & 7 & $7.67 \%$ \\
3. & 10 & $1.85 \%$ \\
4. & 15 & $2.5 \%$ \\
5. & 20 & $2.9 \%$ \\
\hline
\end{tabular}

Ditinjau berdasarkan APVMA metode uji yang digunakan dalam penelitian ini memenuhi syarat \% RSD yang diterima karena konsentrasi komponen terukur $\leq 0.10 \%$ atau $\leq 100$ ppm dengan syarat keberterimaan $\leq 20$ $\%$.

Tabel 4.2 Tingkat presisi berdasarkan konsentrasi analit yang dianalisis berdasarkan American pre-
Veterinary Medical Assosiation (2004)

\begin{tabular}{ll}
\hline $\begin{array}{l}\text { Jumlah komponen terukur } \\
\text { dalam sampel }\end{array}$ & $\begin{array}{l}\text { Tingkat } \\
\text { presisi }\end{array}$ \\
\hline$\geq 10.00 \%$ & $\leq 2 \%$ \\
$1.00 \% \leq \mathrm{x} \leq 10.00 \%$ & $\leq 2 \%$ \\
$0.10 \% \leq \mathrm{x} \leq 1.00 \%$ & $\leq 10 \%$ \\
$\leq 0.10 \%$ & $\leq 20 \%$ \\
\hline
\end{tabular}

Tabel 4.3 Tingkat presisi disesuaikan juga dengan konsentrasi komponen dalam sampel nerdasarkan AOAC.

\begin{tabular}{lc}
\hline \multicolumn{1}{c}{ Konsentrasi } & Presisi \\
\hline $100 \%$ & $\leq 1 \%$ \\
$10 \%$ & $\leq 1,5 \%$ \\
$1 \%$ & $\leq 2 \%$ \\
$0.1 \%$ & $\leq 3 \%$ \\
$0.01 \%(100 \mathrm{ppm})$ & $\leq 4 \%$ \\
$10 \mathrm{ppm}$ & $\leq 6 \%$ \\
$10 \mathrm{ppb}$ & $\leq 15 \%$ \\
\hline
\end{tabular}

Bila digunakan acuan AOAC maka hanya konsentrasi 10,15 dan 20 ppm yang memenuhi syarat keberterimaan yakni $\leq 4 \%$ untuk konsentrasi 15 dan 20 ppm sedangkan $\leq 6 \%$ untuk konsentrasi $10 \mathrm{ppm}$. Adanya variasi pada hasil presisi dapat disebabkan karena kesalahan acak. Kesalahan acak merupakan kesalahan dalam penggukuran karena gangguan dan perbedaan kondisi setiap pengukuran sehingga dihasilkan angka yang berbeda.

Tabel 4.4 Syarat keberterimaan \% recovery disesuaikan dengan konsentrasi berdasarkan AOAC.

\begin{tabular}{lc}
\hline \multicolumn{1}{c}{ Konsentrasi } & $\begin{array}{c}\text { Batas } \\
\text { Recovery }\end{array}$ \\
\hline $100 \%$ & $98-101 \%$ \\
$10 \%$ & $95-102 \%$ \\
$1 \%$ & $92-105 \%$ \\
$0.1 \%$ & $90-108 \%$ \\
$0.01 \%(100 \mathrm{ppm})$ & $85-110 \%$ \\
$10 \mathrm{ppm}$ & $80-115 \%$ \\
$10 \mathrm{ppb}$ & $70-125 \%$ \\
\hline
\end{tabular}




\subsubsection{NIlai LOD dan LOQ}

Berdasarkan perhitungan diperoleh nilai LOD sebesar $2.31 \mathrm{mg} / \mathrm{L}$ sedangkan nilai LOQ sebesar 7.71 $\mathrm{mg} / \mathrm{L}$. Nilai LOD berguna untuk mengetahui jumlah terkecil analit dalam sampel yang masih dapat dideteksi oleh instrument sedangkan nilai LOQ menunjukkan jumlah terkecil analit dalam sampel yang masih memenuhi kriteria presisi dan akurasi. Berdasarkan hasil perhitungan diperoleh konsentrasi terkecil analit dalam sampel yang dapat terdeteksi adalah $2.31 \mathrm{mg} / \mathrm{L}$ dan konsentrasi terkecil analit dalam sampel yang memenuhi kriteria presisi dan akurasi namun masih dapat dideteksi adalah $7.71 \mathrm{mg} / \mathrm{L}$.

Jika ditinjau berdasarkan hasil perhitungan LOQ maka hal ini sesuai dengan perhitungan presisi yang menunjukkan bahwa konsentrasi 3 dan 7 ppm menghasilkan nilai presisi yang kurang memenuhi kriteria jika menggunakan acuan keberterimaan presisi AOAC.

\subsubsection{Akurasi}

Hasil perhitungan terhadap larutan standar 10 dan $15 \mathrm{ppm}$ diperoleh $\%$ recovery yakni $84,3 \%$ dan $87 \%$. Berdasarkan AOAC syarat keberterimaan \% recovery disesuaikan dengan konsentrasi yang digunakan. Tabel 4.4 menunjukkan syarat keberterimaan \% recovery disesuaikan dengan konsentrasi berdasarkan AOAC.

Maka jika ditinjau berdasarkan tabel AOAC, hasil \% recovery pada konsentrasi 10 dan $15 \mathrm{ppm}$ telah memenuhi syarat keberterimaan.

4.2 Pengaruh Perlakuan Derivatisasi Terhadap Hasil Pengukuran Larutan Standar Acetaminophen

Dipilihnya BSTFA sebagai agen penderivat karena BSTFA mampu bereaksi dengan berbagai senyawa organik polar dengan menggantikan hidrogen aktif dengan trimetilsilil $\left(\mathrm{Si}\left(\mathrm{CH}_{3}\right)_{3}\right)$, selain itu BSTFA bereaksi lebih cepat dibandingkan penderivat dengan prinsip sililasi lainnya seperti bis(trimetilsilil)asetamida atau BSA sedangkan TMCS berguna untuk meningkatkan reaktivitas BSTFA (Regis, 1998). BSTFA yang mengandung $1 \%$ TMCS merupakan reagen sililasi yang memiliki sifat pelarut yang baik serta dapat berfungsi tanpa melakukan penambahan pelarut lainnya (Knapp, 1979).

$\begin{array}{clr}\text { Pada } & \text { larutan } & \text { standar } \\ \text { acetaminophen } & 20 \quad \mathrm{ppm} & \text { yang }\end{array}$ diinjeksikan ke dalam sistem GC-MS tanpa perlakuan derivatisasi, diperoleh hasil puncak yang tidak beraturan dan cenderung lebih dari 1 puncak. Hal ini dapat disebabkan senyawa acetaminophen tidak stabil pada suhu tinggi sehingga dapat terdekomposisi parsial yang menyebabkan terdapat beberapa puncak acetaminophen yang sama namun dengan waktu retensi yang berbeda, sehingga konsentrasi senyawa menjadi tidak dapat diketahui melalui peak area. Maka metode tanpa derivatisasi kurang laik digunakan dalam menganalisis senyawa acetaminophen menggunakan GC-MS. Gambar 4.2 menunjukan kromatogram senyawa acetaminophen pada larutan standar tanpa derivatisasi sedangkan Gambar 4.3 merupakan kromatogram senyawa acetaminophen pada larutan standar (derivatisasi) menggunakan mode SIM

$\begin{array}{clr}\text { Pada } & \text { larutan } & \text { standar } \\ \text { acetaminophen } & 20 \mathrm{ppm} & \text { yang }\end{array}$ diinjeksikan ke dalam sistem GC-MS dengan perlakuan derivatisasi, diperoleh hanya 1 puncak untuk senyawa acetaminophen, yakni dalam bentuk acetaminophen-TMS. AcetaminophenTMS $\left(\mathrm{C}_{11} \mathrm{H}_{17} \mathrm{NO}_{2} \mathrm{Si}\right)$ merupakan derivat acetaminophen akibat pergantian gugus $\mathrm{H}$ dengan Trimetilsilil $\left(\mathrm{Si}\left(\mathrm{CH}_{3}\right)_{3}\right)$ pada molekul NH. Perubahan senyawa menyebabkan terjadinya perubahan berat molekul (BM). Senyawa acetaminophen-TMS memiliki BM $223.34 \mathrm{~g} / \mathrm{mol}$ dengan ion fragmentasi 
yang memiliki kelimpahan tertinggi antara lain : 166, 181, dan 223.

\subsection{Analisis senyawa acetaminophen} pada spesimen rambut

Analisis dilakukan pada 10 sukarelawan yang mendapatkan terapi acetaminophen kemudian diambil spesimen rambutnya pada panjang $0-3$ $\mathrm{cm}, 0-6 \mathrm{~cm}$ dan 0-10 $\mathrm{cm}$ untuk dianalisis. Dari 10 orang subyek penelitian, 2 diantaranya tidak terdeteksi senyawa acetaminophen, sedangkan 8 lainnya terdeteksi senyawa acetaminophen dalam bentuk acetaminophen-TMS. Sebagai pembanding maka digunakan sampel blanko yang diperoleh dari sukarelawan yang tidak mendapatkan terapi acetaminophen dan dibuat larutan standar acetaminophen dengan konsentrasi tertentu. Gambar 4.1 merupakan kromatogram blanko (full scan)

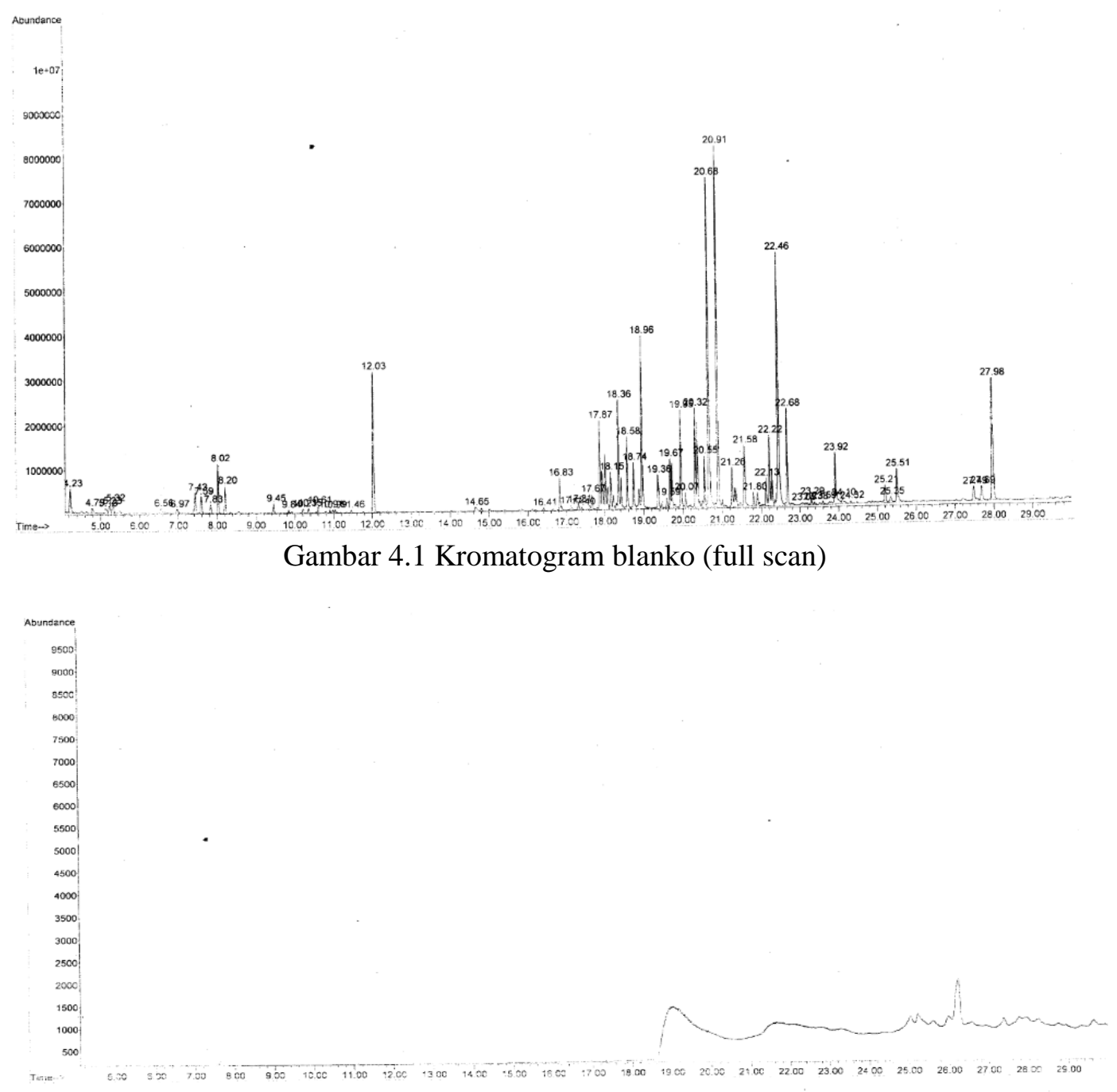

Gambar 4.2 Kromatogram senyawa acetaminophen pada larutan standar (tanpa derivatisasi) menggunakan mode SIM. 


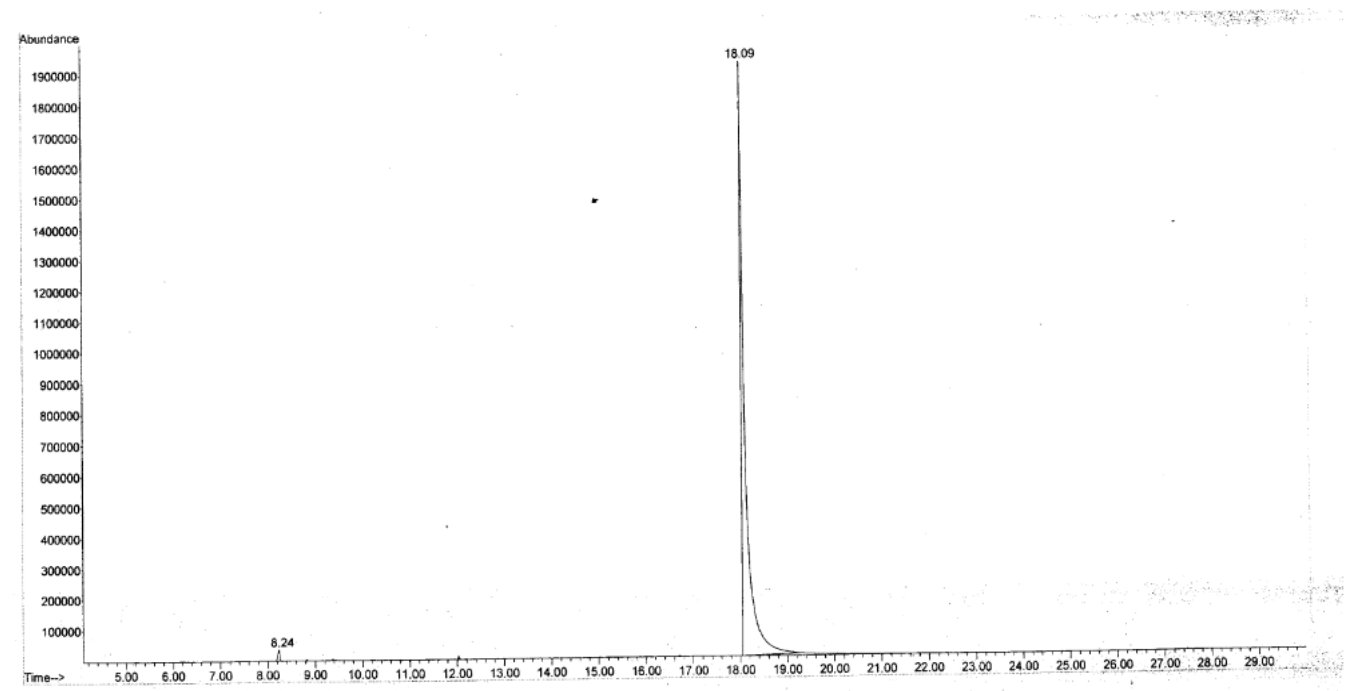

Gambar 4.3 Kromatogram senyawa acetaminophen pada larutan standar (derivatisasi) menggunakan mode SIM

Pada larutan standar dengan konsentrasi $20 \mathrm{ppm}$ muncul 1 puncak pada waktu retensi 18.09 menit yang ditinjau berdasarkan Ion fragmentas dan library

C:IDatabaselwiley7n.1 merupakan acetaminophen-TMS sedangkan pada blanko terdapat puncak dengan waktu retensi 18.15 menit namun berdasarkan Ion fragmentasi dan Library, senyawa tersebut adalah Piridinkarboksaldehid. Pada sampel muncul puncak pada waktu retensi 18.19 menit dan berdasarkan ion fragmentasi didukung Library senyawa tersebut merupakan Acetaminophen-TMS. Gambar 4.4 menunjukkan kromatogram senyawa acetaminophen pada sampel spesimen rambut. Terlihat beberapa puncak lain selain puncak acetaminophen karena spesimen rambut tersusun atas berbagai macam senyawa lain yang bersifat kompleks sehingga memungkinkan bagi senyawa lainnya ikut terekstraksi dan terdeteksi.

Terdapat 2 sampel yang
menunjukkan hasil bahwa
acetaminophen tidak terdeteksi pada
spesimen rambut, hal ini disebabkan:

1. Faktor dosis obat yang pernah dikonsumsi sebelumnya.

2. Faktor rute perjalanan acetaminophen setelah dikonsumsi.

3. Konsentrasi acetaminophen pada spesimen rambut di bawah limit deteksi.

4. Jumlah spesimen rambut yang sedikit.

4.4 Pengaruh panjang spesimen rambut terhadap konsentrasi acetaminophen pada spesimen rambut

Dari 8 subyek yang terdeteksi senyawa acetaminophen maka dilakukan perhitungan untuk mengetahui kadar acetaminophen. Berdasarkan hasil perhitungan diketahui pada panjang spesimen rambut $0-3 \mathrm{~cm}$ konsentrasi acetaminophen 0,1761$0,3392 \mathrm{ng} / \mathrm{mg}$ spesimen rambut, pada panjang spesimen rambut $0-6 \mathrm{~cm}$ diperoleh hasil 0,2081-0.4845 $\mathrm{ng} / \mathrm{mg}$ spesimen rambut dan pada panjang spesimen rambut $0-10 \mathrm{~cm}$ konsentrasi acetaminophen-TMS dalam sampel adalah $0,2473-0,5782 \mathrm{ng} / \mathrm{mg}$ spesimen rambut. Kemudian dilakukan uji statistik regresi linier sederhana menggunakan software IBM SPSS Statistics 24. 


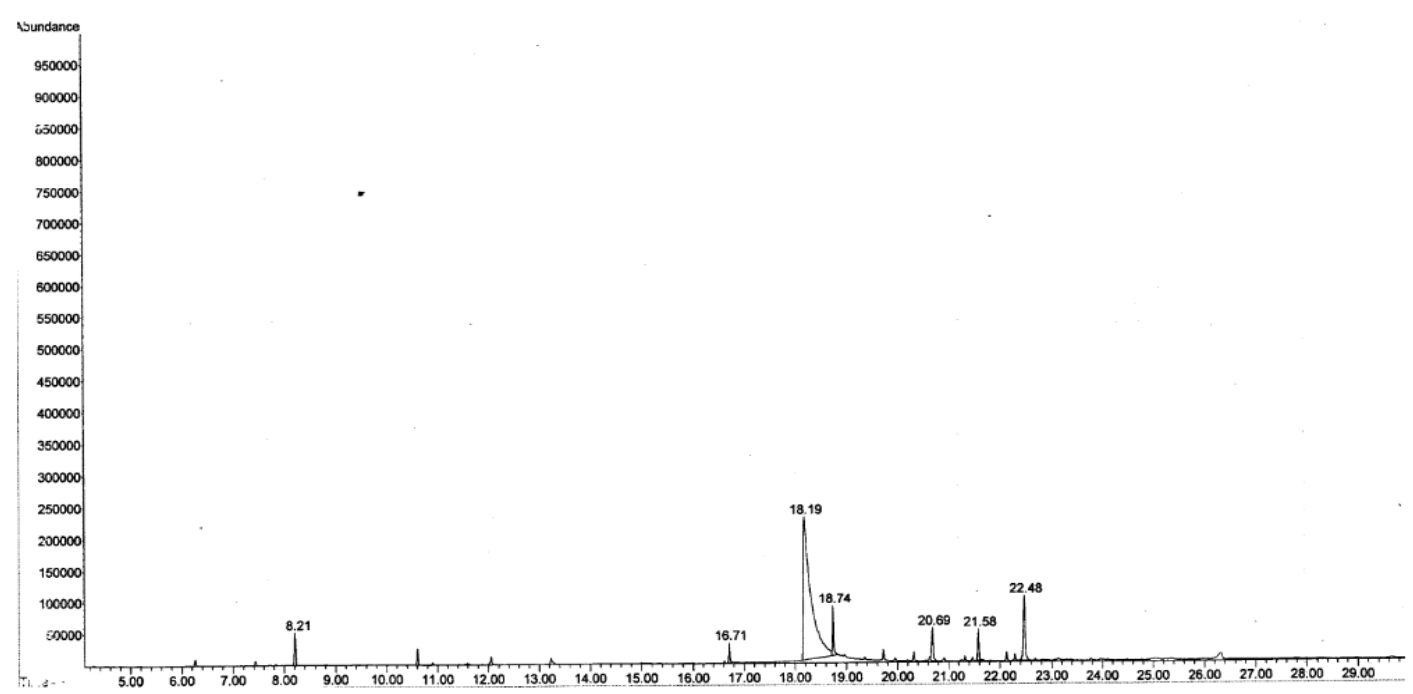

Gambar 4.3 Kromatogram senyawa acetaminophen pada sampel spesimen rambut 
Tujuan uji regresi linier sederhana ini adalah untuk mengetahui hubungan pengaruh signifikan variabel independen (panjang spesimen rambut) terhadap variabel dependen (konsentrasi senyawa acetaminophen). Berdasarkan hasil uji regresi linier sederhana diperoleh nilai $r=$ 0.535 yang menunjukkan bahwa $53.5 \%$ dari varians konsentrasi senyawa acetaminophen dapat dijelaskan oleh perubahan dalam variabel panjang spesimen rambut sedangkan $46.5 \%$ sisanya dijelaskan oleh faktor di luar model. Diperoleh persamaaan :

$$
\mathrm{Y}=0.202+0.019 \mathrm{X}+\mathrm{e}
$$

dengan nilai probabilitas (nilai signifikan) adalah 0,007. Nilai ini kurang dari 0.05 yang berarti variabel independen (panjang spesimen rambut) berpengaruh positif dan signifikan terhadap variabel dependen (konsentrasi senyawa acetaminophen). Makna berpengaruh positif artinya makin panjang spesimen rambut maka makin tinggi konsentrasi senyawa acetaminophen pada penelitian ini.

Pada panjang 0-10 $\mathrm{cm}$ diperoleh nilai konsentrasi tertinggi, dapat disebabkan karena dengan panjang spesismen rambut 10 cm maka dapat dikatakan bahwa usia rambut tersebut $\leq 10$ bulan karena menurut Saitoh (1969) rata-rata $0,6-1,42 \mathrm{~cm}$ per bulan, sehingga memungkinkan untuk lebih banyak senyawa obat yang berikatan dengan spesimen rambut.

\section{SIMPULAN DAN SARAN}

5.1 Simpulan

Berdasarkan penelitian ini maka dapat disimpulkan bahwa :

a. Acetaminophen dapat dideteksi pada spesimen rambut menggunakan GC-MS.

b. Perlakuan derivatisasi dapat mengoptimalkan hasil analisis acetaminophen pada spesimen rambut menggunakan GC-MS. c. Terdapat pengaruh panjang spesimen rambut terhadap konsentrasi senyawa acetaminophen yang dianalisis menggunakan GC-MS.

5.2 Saran

Diperlukan penelitian lebih lanjut terhadap senyawa golongan narkotika, psikotropika maupun doping pada spesimen rambut dengan memperhatikan waktu konsumsi dari obat-obatan tersebut. Selain itu perlu dilakukan kembali penelitian dengan menggunakan panjang spesimen rambut yang lebih dari $10 \mathrm{~cm}$ untuk membuktikan ketahanan masing-masing senyawa obat dalam spesimen rambut.

\section{UCAPAN TERIMA KASIH}

Melalui kesempatan ini penulis menyampaikan ucapan terima kasih kepada semua pihak atas saran dan kritiknya sehingga penelitian ini dapat terselesaikan

\section{DAFTAR PUSTAKA}

APVMA, 2004, Guidelines For The Validation Of Analytical Methods For Active Constituent, Agricultural And Veterinary Chemical Product, Kingston APVMA, Australia.

Aronson, J.K., 2014, Side Effect of Drug Annual 35, University of Oxford, Elsevier

Asquith, R.S., 1977, Chemistry of Natural Protein Fiber, Plenum Press, New York and London

Castanet, J. and Ortonne, J.-P., 1997, Hair melanin and hair color, Formation and Structure of Human Hair, pp. 209-225.

David, G. W., 2005, Analisis Farmasi, Edisi kedua, EGC, Jakarta

Drozd, J., 1985, Chemical Derivatization in Gas Chromatography, Journal of Chromatography Library, 19

Forte, J.S., 2002, Paracetamol : Safety Versus Toxicity, (2)

Granberg, R.A and Åke C. Rasmuson, A.C, 1999, Solubility of Paracetamol in 
Jurnal Biosains Pascasarjana Vol. 18 (2016) pp

(C) (2016) Sekolah Pascasarjana Universitas Airlangga, Indonesia

Pure Solvents, J. Chem. Eng., 44 (6) : 1391-1395

Han, E.,Chung, H., soong, J.M., 2012, Segmental Hair Analysis for 11Nor- $\Delta^{9}$-tertrahydrocannabinol-9Carboxylic Acid and the Patternsof Cannabis Use, Journal of Analytical Toxicology, $32: 195-200$

Hansen, S., Bjergaard, S.P., Rasmussen, K., 2012, Intrduction to Pharmaceutical Chemical Analysis, Wiley, UK

Kintz, P., 2000, Hair, In: Jay A. S. editors. Encyclopedia of Forensic Sciences, Vol II. UK : Academic Press. p. 598-640

Kintz, P., 2007, Analytical and Practical Aspects of Drug Testing in Hair, Taylor and Francis Group, CRC Press

Knapp, D.,R., 1979, Handbook of Analytical Derivatization Reactions, New York

Lamke, T.L., Williams, D.A., Roche, V.F., Zito, S.W., 2007, Medicinal Chemistry Sixth Edition, USA

Moffat, C. A., M. D. Osselton, and B. Widdop. 2004. Clarke's Analysis of Drugs and Poisons. Great Britain: Pharmaceutical Press
Moffat, C. A., M. D. Osselton, and B. Widdop. 2005. Clarke's Analysis of Drugs and Poisons. Great Britain: Pharmaceutical Press

Mozayani, A., and Raymon, M.P., 2002, Handbook of Drug Interactions A Clinical and Forensic Guide, Humana Press

Pötsch, L., A discourse on human hair fibers and reflections on the conservation of drug molecules, Int. J. Legal Med., 108, 285-293, 1996.

Saitoh, M., 1969, Rate of Hair Growth in Advances in Biology of Skin, Oxford, Pergamon Press p.183-201

Saito, T., Morita, T., Inoue, S., Yamamoto, I., and Inokuchi, S., 2008, GC-MS assay for acetaminophen in human hair segments, Forensic Toxicol 26:27-30

Sparkman, O.D., Penton, Z., Fulton, G., 2011, Gas chromatography and mass spectrometry : a practical guide, Elsevier

Wijayaputra, N., 2011, Deteksi Senyawa Metamfetamin (MA) Pada Rambut dengan Metode SIM GC-MS, Tesis, Universitas Udayana, Denpasar 